\title{
Not seeing Auschwitz: memory, generation and representations of the Holocaust in twenty-first century French comics
}

\section{Claire Gorrara}

To cite this article: Claire Gorrara (2018) Not seeing Auschwitz: memory, generation and representations of the Holocaust in twenty-first century French comics, Journal of Modern Jewish Studies, 17:1, 111-126, DOI: 10.1080/14725886.2017.1382107

To link to this article: https://doi.org/10.1080/14725886.2017.1382107

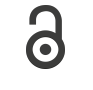

(c) 2018 The Author(s). Published by Informa

UK Limited, trading as Taylor \& Francis Group

曲 Published online: 02 Jan 2018.

Submit your article to this journal ๘

Џ Article views: 15

Q View related articles $\sqsubset$

View Crossmark data ¿ 


\title{
Not seeing Auschwitz: memory, generation and representations of the Holocaust in twenty-first century French comics
}

\author{
Claire Gorrara \\ School of Modern Languages, Cardiff University, Cardiff, UK
}

\begin{abstract}
We are reaching a point in history when the generation who experienced the Holocaust as survivors, witnesses or exiles will soon disappear. What happens to our relationship to such a momentous event in global history when our living connection with such a past is broken? To answer this question, this article will explore recent French representations of the Holocaust through the comic book. It will approach such representations from the perspective of the grandchildren of those who were affected by the Holocaust, perhaps the last generation to have personal ties to this wartime past. It will focus specifically on Jérémie Dres's Nous n'irons pas voir Auschwitz (2011), translated as We Won't Go and See Auschwitz. As a "third generation" narrative, Dres's work is attentive to stories of Jewish exile and loss to be found on the margins of Holocaust histories. This perspective translates into an openness towards transnational histories of the Holocaust; a recognition of place as a substitute for living memory and an awareness of comics' potential to innovate in the transmission of Holocaust memories. Ultimately, this article will argue that the contemporary comic book acts as a privileged vehicle of remembrance, indicative of the reordering of Holocaust representations in an age of cultural memory.
\end{abstract}

\section{KEYWORDS}

Holocaust; comics; Auschwitz; generation; memory

We are reaching a point in history when the generation who experienced the Holocaust as survivors, witnesses or exiles will soon disappear. In this moment, the Holocaust will move from the realm of communicative memory, remembered within the lifetime of a generation, to that of cultural memory, where the past is available to us only via material objects, visual and written narratives and historical sites of memory (Assmann and Czaplicka 1995). What happens to our relationship to such a momentous event in global history when our living connection with this past is broken? To answer this question, this article will explore recent representations of the Holocaust through the comic book. It will approach such representations from the perspective of the grandchildren of those who were affected directly or indirectly by the Holocaust. They constitute

CONTACT Claire Gorrara gorrara@cardiff.ac.uk E School of Modern Languages, Cardiff University, 66a Park Place, Cardiff CF10 3AS, UK

(c) 2018 The Author(s). Published by Informa UK Limited, trading as Taylor \& Francis Group

This is an Open Access article distributed under the terms of the Creative Commons Attribution License (http://creativecommons.org/ licenses/by/4.0/), which permits unrestricted use, distribution, and reproduction in any medium, provided the original work is properly cited. 
perhaps the last generation to have a personal connection to this traumatic past. As a bridge between communicative memory and cultural memory, this "third generation" can reflect on Holocaust representations for the twenty-first century.

This article will examine this transitional phase in Holocaust representations in France. It will focus on the comic book Nous n'irons pas voir Auschwitz (We Won't Go and See Auschwitz, 2011) by Jérémie Dres. It will begin by analysing the comic book as a word and image text that "draws to tell" (Chute 2016,6). What are the medium-specific features of the comic that make it an effective vehicle for representing the memory of traumatic war experiences, such as the Holocaust? It will then evaluate the "generational thinking" (Weissman 2017) that has provided the dominant conceptual model for understanding the transmission of Holocaust memories from direct witnesses and survivors to family members, and within society more broadly. How can notions of generation help us appreciate reconfigurations of the Holocaust into the twenty-first century? The article will then move to the case study of France. It will assess changing post-war discourses on the Holocaust in France and the importance of national contexts for shaping Holocaust representations. How have French comic books responded to a struggle to tell stories of the Holocaust in France? It will then analyse Jérémie Dres's Nous n'irons pas voir Auschwitz, an autobiographical comic book recounting Dres's journey to Poland to discover the family histories and sites of memory of his Polish-Jewish grandparents and great grandparents. ${ }^{1}$

The choice to focus on Nous n'irons pas voir Auschwitz for this article is motivated by its singularity as the only French comic book to date to provide a third generation's perspective on the Holocaust. ${ }^{2}$ Dres's work sits within a small body of memoirs, fiction works and histories produced by French and francophone grandchildren with a family history connected to the Holocaust. ${ }^{3}$ Dres's work has been recognized already as a pioneering example of what Isabelle Delorme (Cases d'Histoire, 2015) terms comics as "memorialising historical narratives." the Holocaust curated by the Mémorial de la Shoah in Paris in 2017. ${ }^{5}$ For Dres's comic book is conceived to listen to stories of Jewish exile and loss located on the periphery of Holocaust histories. This perspective translates into an openness to transnational histories of the Holocaust; a recognition of place as a substitute for living memory; and an awareness of the potential of comics to innovate in the transmission of Holocaust memories. Ultimately, the article will argue that the contemporary comic book emerges from this discussion as a privileged vehicle of remembrance, indicative of the reordering of Holocaust representations in an age of cultural memory.

\section{Comics, memory and drawing to tell}

The comic book has long been considered a medium able to disrupt conventional ways of seeing war. As Hillary Chute notes in her study of histories of visual witnessing, the comic form has offered writers a means of representing the personal impact of war and conflict on individuals and communities via "an ethics of looking and reading that is intent on defamiliarizing standard or received images of history while yet aiming to communicate and circulate" (Chute 2016, 31). In its aesthetic experiments with word and image, the comic book calls attention to the sensory experience of war, represented not only through the sightline of the witness but also bodily in the haptic medium of hand drawings. For the comic book author, "drawing to tell" creates possibilities for representation 
that word-only or image-only forms cannot deliver, whilst for the reader, comics offer a "generative friction" (Chute 2016, 34), where words and images rub up against each other, making for a reading experience that requires a high degree of participation.

These multisensory drawing and reading processes have made comics an attractive choice for comic book authors wishing to represent heightened emotional states, such as those associated with the memory of traumatic events. Comics have the potential to signal memory recall and disruption not only by their choice of plot and theme but also by hard-wiring such memory work into the fabric of the word-image project (Dony and van Linthout 2010). This conjunction of the comic book form and memory is signalled, firstly, in the page layout of comics. The separate panels that function as the basic reading blocks of a comic can be read as "boxes" of memory that require narrative sequencing to make sense of the whole. The "gutter," or blank space between panels, gives the reader the opportunity to make the imaginative leap from one memory experience to another. As such, the page layout of comics demands a cognitive act of connection akin to the psychological need to order memories. Where this is missing or disrupted, trauma can be inferred or represented. Secondly, the reading conventions of comics can work to highlight traumatic memory. Different drawing styles mixed together can show chaotic memory processing. Changing panel shapes and sizes, with enclosed or open borders, influences the pace and rhythm of reading and can be used to denote troubled mental states. The choice of colour palette, or the use of black and white only, equally inflects how the past is represented in the present. Sepia tones can stand for nostalgia and loss, whilst stark colours can symbolize vibrant recall. Via form, therefore, the comic book offers writers a powerful tool for drawing memory that opens a channel for emotive engagement with the past. In the case of the Holocaust, this is an engagement caught up in the dilemmas of memory transmission and representability, as well as the continuing presence of the Holocaust in everyday lives.

\section{Generational thinking}

From the 1970s onwards, scholars have interrogated the processes for transmitting Holocaust memories from one generation to another. Those with a family connection to the Holocaust have often been viewed as privileged custodians of a Holocaust memory and imbued with a moral responsibility to preserve family stories for posterity. Such a responsibility brings with it the burden of faithful transmission and an anxiety that such a traumatic family past will determine the identity of those who come after. For Esther Jilovsky, the Holocaust memories of their parents manifest themselves in the second generation as "a tortured, ambiguous notion of memory that resembles the loss of something they never had" $(2015,68)$. This psychological loss but also longing to know more of such Holocaust experiences has been termed "postmemory" by Marianne Hirsch:

Postmemory characterises the experiences of those who grew up dominated by narratives that preceded their birth, whose own belated stories are evacuated by the stories of the previous generation shaped by traumatic events that can be neither understood nor recreated. $(1997,22)$

For Hirsch, these traumatic events have been transferred to second-generation children in memory fragments; in precious objects, such as photographs; in conversations and 
everyday habits that enter the child's life as an encounter with a dark and unknowable past. More recently, Hirsch has expanded the notion of postmemory to encompass the transfer of traumatic memories beyond a family frame. Writers and artists with no family connection to the Holocaust can be incorporated into a transgenerational model founded upon an ethical imperative to remember the Holocaust as the "generation of postmemory" (Hirsch 2012). In such a way, thinking generationally allows for representations rooted not only in family experiences but also in fictional narratives where authors identify imaginatively with the experiences of direct survivors and witnesses to the Holocaust.

Critics, such as Gary Weissman, have contested the concept of a "generational consciousness" of the Holocaust $(2017,165)$. For Weissman, generational thinking is predicated on a series of flawed premises: that familial proximity to the Holocaust creates a specialness that speaks in a qualitatively different manner to other representations; that generations can be considered as largely homogenous entities who think in comparable ways; that there are common patterns of memory transfer within families that can be generalized to act as a societal framework. Indeed, Weissman makes a persuasive case for recognizing the multiple and varied positions of post-war writers who engage with the Holocaust through the idiom and/or experience of the family. However, if generation cannot be taken as a determining axis for engaging with the Holocaust, how can we account for its influence on those authors and artists drawn to depicting real and fictionalized family acts of memory transfer? We might instead consider generation as only one means of self-identification for a community of Holocaust writers brought together by "sets of meanings, symbols and even literary fictions" (Hoffman 2004, 28).

A small number of writers and artists have consciously claimed affiliation as a "third generation" of grandchildren of the Holocaust. For Erika Dreifus, there is "a special kind of kinship" amongst writers born in the 1960s and 1970s who work at a third generational remove from family experiences of the Holocaust $(2017,1)$. Aarons and Berger (2017) propose some common features for this third-generation community. These are writers who represent the Holocaust via indirect means, above all creative reimagining. With limited direct access to Holocaust survivors, they are less impacted by traumatic recall but still want to know the specifics of their family history. This translates into return journeys to the sites of Holocaust atrocity in Central and Eastern Europe. These journeys of exploration are undertaken with an awareness of the writer's responsibility to act as an "ethical listener, one who recognizes and acts upon [...] 'the duty to listen' [...]" (Aarons 2016, xv). Dres's Nous n'irons pas voir Auschwitz shares many of these third-generation features: the creation of memory sites in words and pictures to fill voids in the family record; the journey back to family spaces and places of remembrance in Poland; a self-conscious excavation of the family's wartime past and the ethical urgency to listen to Holocaust survivors, witnesses and exiles before they pass away. However, what Dres's narrative highlights is the extent to which national debates impact on how the Holocaust is represented.

\section{The Holocaust, French comics and the struggle to tell}

A French comic book was "probably one of the very first mentions in a work of fiction, regardless of art form" of the Holocaust (Bruttmann 2009, 180). In November 1944, La Bête est morte: la guerre mondiale chez les animaux (The Beast is Dead: World War 
Amongst the Animals) by Edmond-François Calvo and Victor Dansette (1995), provided a startling two-volume depiction of the war on a global scale. ${ }^{6}$ La Bête est morte presents the Second World War as a battle of the species, with Germans wolves, Italian pigs and Japanese weasels pitted against British bulldogs, American bison and Russian bears. In one panel, the deportation and extermination of Jews is directly represented as a rabbit mother and child are separated, with the mother made to climb into a cattle wagon, destination unknown but travelling "via Berlin." In this one panel, the comic book sets out a French period narrative of the Holocaust from 1944. This is one in which the Germans are the perpetrators of the Holocaust, represented as an act of inhumanity against a defenceless population. The Jewish population is not distinguished as a group and their treatment sits within a spectrum of war crimes, including mass shootings and population displacement. The role of the French state in facilitating such crimes is not implied or acknowledged, as a Manichean vision of war separates the good from the evil.

In this early depiction of the Holocaust in comics, La Bête est morte was in tune with broader representations of the Holocaust in French culture. As historian Henry Rousso has claimed in his study of the "Vichy syndrome" in French public life, the early postwar years in France were given over to a period of mourning to be followed by the ascendency of the resistance, above all in its Gaullist incarnation, in the late 1960s (1987). The Holocaust was present in national debates but was not spoken about in the terms that are used today, giving rise to the notion that there was a "great silence" about the Holocaust in French public life in these early decades (Azouvi 2012). From the 1970s, darker representations of occupation and collaboration gained prominence as a younger generation began to probe the war record of their parents' generation. Memories of collaboration were, in many instances, accompanied by reflections on French anti-Semitism and the role of the Vichy regime in the deportation of Jews from France to extermination camps in the East. Since the 1990s, commemoration has been central to French public discourses on the Holocaust. France was the first European country to decree a day of national commemoration for the victims of the Holocaust in 1993. Yet, it has been the fraught process of coming to terms with the anti-Semitism of the Vichy regime that has had the most significant impact on a specifically French "Holocaust consciousness" (Wolf 2003, 2). When in 1995 then President Jacques Chirac acknowledged the role of the French state in wartime anti-Semitism on the 53rd anniversary of the rafle du Vélodrome d'Hiver, he was the first one to make this frank admission. ${ }^{7}$ Into the twenty-first century, the Holocaust continues to act as a contested reference point in French national history. There may be a "depoliticised surface-level consensus" but this covers a "deeply challenging, markedly divided and inherently political communal discussion about the meaning of the wartime past in contemporary society" (Clifford 2013, 257).

In line with these public discourses on the Holocaust, French comic books rarely broached the subject of the Holocaust with notable and controversial exceptions, such as the 1980s series Hitler =SS by Philippe Vuillemin and Jean-Marie Gourio, which used scatological black humour to represent the camps. ${ }^{8}$ However, by the 1990s, French comic book artists began to integrate the Holocaust into their work as either a plot structuring device or via real-life or fictionalized personal accounts. ${ }^{9}$ Pascal Croci's Auschwitz ([1999] 2012), for example, immerses the reader in the extermination camps through a flashback device triggered by the civil war in the former Yugoslavia. This attempt to draw from within the univers concentrationnaire has been an unusual choice for French 
comic artists. Since the 2000s, the emphasis has been on discovering lost or neglected memories of the Holocaust, in both autobiographical and fictional comic book narratives. This movement has been driven in part by the national culture of commemoration and in part by the realization that Holocaust survivors and witnesses are passing away. In this context, the trope of a parent or grandparent handing on their memories to younger family members remains a popular narrative device. This trope has been adopted by comic book authors confronting other troubling familial memories of the Second World War, above all the exile and internment of French prisoners of war. Second- and third-generation authors and artists, such as Jacques Tardi and Florent Silloray, have made use of the comic book format to depict the capture and long march from France to German prisoner of war camps of their close relatives. Handwritten period diaries play a key role as source text but also as an integral element of the graphic texture of the past, cementing the relationship between the comic book author and a now deceased father and grandfather. ${ }^{10}$ Dres's Nous n'irons pas voir Auschwitz, therefore, sits within a larger context where the comic book is making a significant contribution to the reshaping of wartime histories from the perspective of authors positioned at the transition point between lived experience and cultural memory.

\section{Nous n'irons pas voir Auschwitz and a willingness to listen}

Nous n'irons pas voir Auschwitz is Jérémie Dres's first full-length comic book. It was followed by Dispersés en Babylone (2014), a comic book account of his trip to Jamaica in search of the roots of Judaism and Rastafarianism. In both comic books, Dres uses a quest narrative to explore cultural histories and intellectual debates that relate to his family history and cultural identity as a non-observant Jewish Frenchman. Since Nous n'irons pas voir Auschwitz, Dres has adapted this autobiographical format for other graphic narratives that depict his encounters with, for example, the minority Armenian, Jewish and Greek communities of Istanbul or Syrian refugees living in displaced persons camps in Iraq. ${ }^{11}$ What unites these works is Dres's self-projection as an attentive listener and receiver of other peoples' stories. As such, Dres's full-length comic books are committed to an ethics of intercultural understanding that speaks to a third generation's "duty to listen" to personal and collective stories of the Holocaust.

Nous n'irons pas voir Auschwitz developed as a project following the death of Dres's paternal grandmother, Téma Barab, in 2009 in Paris, aged 97. Born and brought up in Warsaw in a bourgeois assimilated Jewish family, Téma and three of her four siblings migrated to either France or America in the interwar years. Only one "poor Sonia" (Dres 2012, 108) appears to have died in the Holocaust, as did Dres's paternal great grandfather, Tankiel Dress, noted in captions that accompany family photographs at the end of the book. Téma's stories of life in pre-war Poland set the scene for Jérémie and his older brother Martin's to visit Poland in July 2010. They go in search not of Sonia and the extermination camps but of the traces of Téma's own parents from Warsaw, Mozsek Barab and Chana Glicka Barab, who died in 1918 and 1932, respectively, and the Dress family who came from the small town of Żelechów. This is a narrative that refuses the "backshadowing" effect so cogently analysed by Michael Bernstein whereby the cataclysm of the Holocaust is reflected back so as to overwhelm the varied histories and social world of European Jewish life prior to the rise of Nazism (1998). The brothers end their journey at the annual 
Jewish festival in Kraków, 50 kilometres from Auschwitz, but they decide not to visit the camp complex and museum. This choice not to visit Auschwitz shapes the whole journey. For this is not a third generation's quest to reflect on the Holocaust as the rupture point in Jewish history. It is, rather, an attempt to reconstitute and understand the history of the Jewish community in wartime Poland and its legacies for post-war generations.

Drawn in monochromatic black and white and divided into chapters with headings, the comic book gives the autobiographical narrator's reflections on the ongoing journey. Family photographs are reproduced in an appendix, as well as a short text by his brother Martin, entitled, "She was called Téma." Different intratextual family voices complement the autobiographical narrator's meditations, although the voice of his father as the second generation is muted and only heard briefly in pre-journey sequences warning the brothers to "[...] watch out for Polacks" (Dres 2012, 8). A prologue by a French historian of Poland, Jean-Yves Potel, sets the context for this third-generational journey. Such authenticating material locates Dres's project as part of a broader cultural movement to rescue and recover marginalized stories of the Shoah. This translates into an openness to transnational histories of the Holocaust; a recognition of place as a substitute for living memory and an awareness of the potential of comics to innovate in the transmission of memories of the Holocaust.

\section{Transnational histories}

From the first panel, Nous n'irons pas voir Auschwitz represents the autobiographical narrator as on a journey of discovery. Jérémie has arrived in Warsaw and is attempting to locate his grandmother's former home. Walking through the streets of Warsaw, street map in hand, he is confused by the contemporary street names, so different from those his grandmother remembered. He is disorientated and disappointed by how few topographical traces remain of Warsaw's vibrant pre-war Jewish community following post-war reconstruction, described as undertaken "for Poland's greater glory" but in fact springing from "a selective remembering" (Dres 2012, 2). These "First Steps" in Warsaw appear to confirm family anxieties about visiting Poland as hostile territory and as a country in which he will not be welcome as a third-generation Jewish descendent. Yet the comic book focuses on the many people in Poland who enable Jérémie to recover his family history. These interlocutors connect the brothers' family history to a Jewish diaspora that extends and challenges what it means to be Jewish in contemporary society: from Polish and American Orthodox and Reform rabbis to fashionable Jewish journalists to Jewish militants who were once active under state socialism and lived abroad to evade capture and arrest in more politically sensitive times. The outcome of such encounters and personal trajectories is to open a transnational circuit for Jewish histories and memories in which France, the starting point for Jérémie's journey, moves from the centre of narrative gravity to the margins.

Nous n'irons pas voir Auschwitz makes clear that Jérémie and Martin follow a welltrodden path as they seek to understand their family history. The comic book presents such a quest as "root tourism" by drawing attention to a plethora of stories about Polish Jews. These range from the stories of Jews who lived under Soviet wartime occupation to experiences of widespread Polish anti-Semitism, such as the post-war pogroms in Kielce, Kraków and Katowice. This heritage of loss is frequently drawn 
against the backdrop of maps or iconic buildings and landscapes as if to accentuate the connections between received history and the personal accounts of the brothers' interlocutors. Indeed, co-production of knowledge and memory is emphasized as the comic book draws attention to the network of French and Polish experts and storytellers on whom the brothers rely. Stories of the wartime past are never drawn as disembodied information but as emanating from named interlocutors via speech bubbles or free-floating text recounted in the first person. Nous n'irons pas voir Auschwitz, therefore, figuratively acknowledges the debt the brothers owe to others who translate and interpret Polish sources for them.

Transnational histories bring with them the translational challenges of reconstituting a Polish-Yiddish past for grandchildren for whom such languages and cultures are foreign. English operates as a supposedly neutral lingua franca in the stilted conversations that allow the brothers to make first contact with their many Polish interviewees. However, the comic book also provides examples of missed communication, emphasizing how the experiences of older Polish family members can be lost in translation. This is represented poignantly in the chapter "Cold Sweat in Żelechów" when the brothers attempt to access the local archives in search of the family records of their paternal grandfather Simchy Dress. Drawn as starting their conversation with halting English "We'd like to make some researches about a family who lived here long time ago ..." (Dres 2012, 134), the brothers are confronted with incomprehension by the local archivists who respond firstly in Polish and then in fragmented English. The brothers cannot penetrate the linguistic and bureaucratic barriers that separate them from their Polish family's past. In a panic, Jérémie disowns their family history: "No, no, this is not us, this is not our family. We do it for a friend in France, we are French and ..." (Dres 2012, 137). Anxiety is depicted as radiating from him in circular lines suggesting flapping hands or vigorous head movements. The refraction of their family history through three languages symbolizes the communicative challenges that emerge when Holocaust stories are loosened from the anchor of the wartime generation.

\section{Sites of memory}

In Nous n'irons pas voir Auschwitz, place comes increasingly to act as a substitute for memory, standing in for the wartime generation. The comic book transitions between three locations in Poland (Warsaw, Żelechów and Kraków) and three in Paris (Jérémie's apartment, that of Téma, his grandmother, and the municipal cemetery at Bagneux where Téma is buried). For whilst Téma is the privileged interlocutor for the early chapters, locations in Poland act as milestones for the personal journey undertaken by Jérémie and Martin. Key to the spatial coordinates of memory in the comic is the absence of Auschwitz and Dres's decision to site Jewish wartime memory elsewhere in a "Big Bang" dispersal of memory sites. These other locations include the sole surviving synagogue from the war years in Warsaw, the trace of the boundary wall of the Warsaw ghetto and the project to restore Prosna Street in the former Jewish district of Warsaw as a world heritage site. Yet if Auschwitz is rejected as the destination for the brothers' journey, its effects are visible in displaced form, above all in panel sequences that focus on cemeteries. These are both sites of remembrance and metaphors for contemporary responses to the wartime past across French and Polish cultures. 
Cemeteries come to signify the ambivalent nature of Polish responses to the Holocaust and reinforce a prevalent representation of European Jewry as a "cemetery culture" of doomed people (Bernstein 645). The first cemetery sequence takes place in Warsaw as Jérémie and Martin discover the graves of Téma's parents. In a chapter entitled “The Jungle of the Forgotten," the brothers locate Moszek's and Chana Glicka Barab's tombstones thanks to the Jewish cemetery director, Isroel Szpilman, who is digitally mapping the cemetery. He acts as their guide when, surrounded by vegetation, the tombstones emerge like newly discovered treasure. The brothers appear as intrepid explorers, astounded by this eureka moment of discovery. Even if the damaged tombstones do not yield up all the information the brothers seek, this panel sequence offers an image of the stewardship of Jewish memory and a commitment to repair a broken chain of memory transmission.

The Jewish cemetery in the small town of Żelechów, the birthplace of the brothers' paternal grandfather, Simchy Dress, is another matter. The panel sequence begins with a car journey describing the difficulty of locating Simchy's former home. It is now a factory for electrically operated doors with a full-scale Madonna erected in the garden, suggesting both an attempt to erase a Jewish heritage and a desire to "close the door" on the past. The brothers' discovery of the Jewish cemetery of Żelechów is an indictment of the neglect and indifference felt by the local population towards this wartime past. This is made visible in a full-page panel (Figure 1).

Unlike other panels in this talky comic book, the reader has only Martin's tense "Let's not hang about, okay?" (Dres 2012, 129) to gauge the brothers' response. Overgrown vegetation is more pronounced than in the Warsaw cemetery sequences and the graveyard is scarcely visible as a site of remembrance, resembling an abandoned field. The brothers enter via cross-wire fencing reminiscent of an entrance to no-man's land. The tombstones appear as broken teeth peeking through long grasses and the reader is positioned in perspectival terms to share the brothers' sense of the desolation. In this single-page panel, the brothers are small figures in a larger landscape of loss with no sign or referent that would give value or meaning to this final resting place for the large Jewish community of Żelechów, now completely vanished. This panel represents a localized memory of denial in contrast to Warsaw. Such sequences demonstrate how the capital and the regions do not project comparable visions of Poland's wartime past, the ruins of Żelechów standing in stark opposition to the thriving Jewish communities of Warsaw and Kraków.

\section{Comics and cultural transmission}

If physical sites of memory in Poland offer conflicting visions of the past in the present, Nous n'irons pas voir Auschwitz highlights the bridging role played by the third generation. The autobiographical narrator seeks to balance the oral testimony of his grandmother with the cultural knowledge he acquires on his journey and has absorbed previously. Yet the very title of the comic book sets out the challenges for a third generation when faced with the presence of the Holocaust in twenty-first century culture. ${ }^{12}$ Dres does not want to "see" Auschwitz, an indicator of his unease around the packaged déjà vu of Holocaust tourism and the ritual of group visits to the concentration camps. ${ }^{13}$ For the third generation, the pilgrimage to Auschwitz is hedged with difficulties. It begs the question of how far "seeing" Auschwitz can inform understandings of a traumatic family past or 


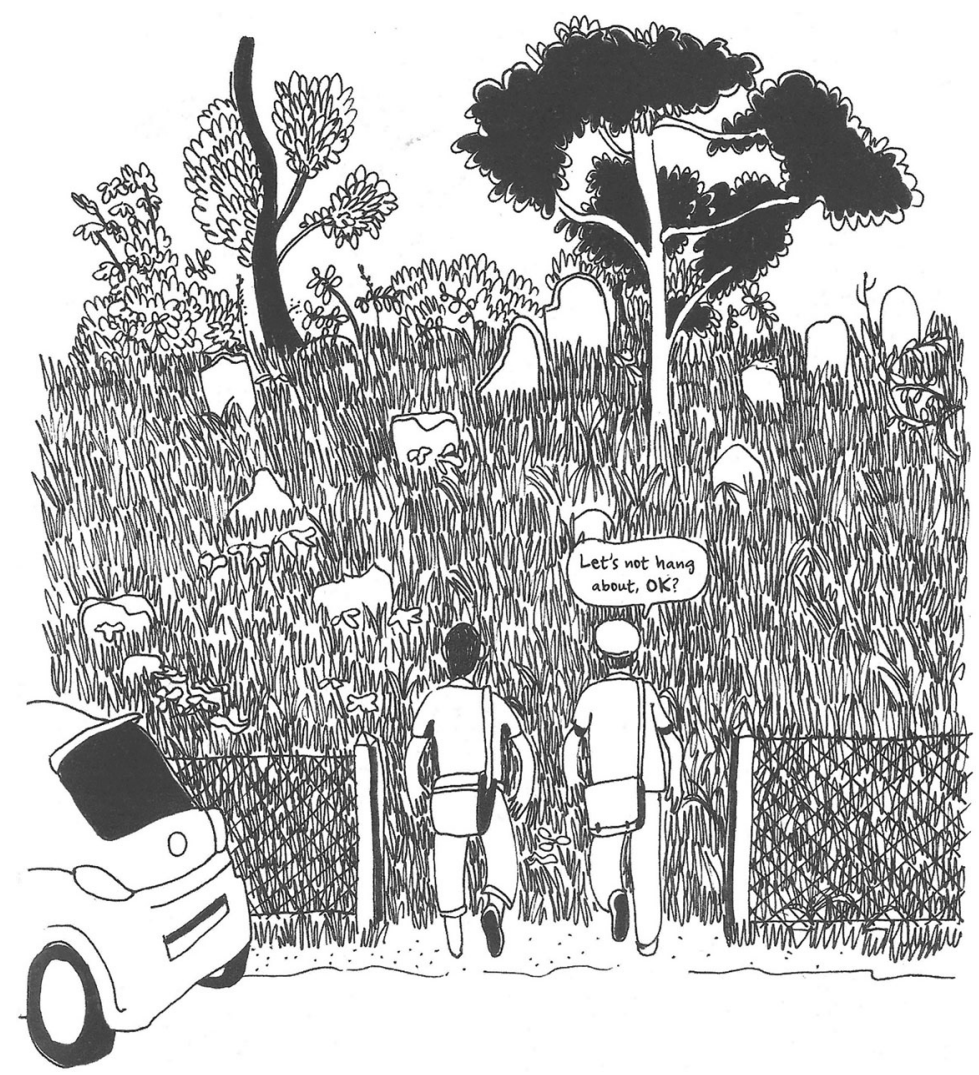

Figure 1. Nous n'irons pas voir Auschwitz, Jérémie Dres, éditions Cambourakis (2011), translated as We Won't Go and See Auschwitz, SelfMadeHero (2012): 129, reproduced with the kind permission of the author.

even impede a meaningful connection. Yet if we "don't go and see Auschwitz," what else do we see and how can we encounter the wartime past? In Nous n'irons pas voir Auschwitz, the comic book proves central to a third generation's relationship to the Holocaust.

Nous n'irons pas voir Auschwitz uses the word-image combination of the comic book to highlight the multiple worlds from which Jérémie builds his relationship with the Holocaust. Using different genres of drawing, the comic book demonstrates different ways of engaging with the past. These include a documentary mode and the remediation of period photographs, such as the group family portraiture that Dres redraws as part of the back story to Téma's Polish life $(2012,108)$ and then reproduces in the annex. Dres also creates flamboyant dreamscapes of a pre-war Jewish Poland. In these sequences, the autobiographical protagonist is drawn dwarfed by his imagined ancestors as their "larger than life" presence overwhelms a scene of pre-war shtetl life (Dres 2012, 165168). These imagined scenes contrast with detailed portraits of the French, Polish and American interlocutors whom the brothers meet on their journey. Each portrait is accompanied by the name of the interviewee transcribed in bold text underneath. Such differentiation and graphic exactitude makes clear Dres's ethical "duty to listen" and to respect his interlocutors as custodians of memory. For this is a journey into the past in 
the digital age, conscious of the dangers that come with a surfeit of computer-generated memory. This is intimated in drawn images of jpeg tagged photographs, iPhone text messages and screen shots of database record searches. The digital media of memory revolutionize what can be found in an age of accelerated information retrieval. However, virtual sources are not the primary sources for navigating the gap between lived reality and cultural memory.

The defining interlocutor for Nous n'irons pas voir Auschwitz is another comic, Art Spiegelman's Maus (2003), the paradigmatic example of postmemory and the second generation. Connections are evident at the level of characterization, narrative structure and aesthetics. The figure of Vladek, Artie's father and an Auschwitz survivor, finds his counterpart in the figure of Dres's paternal grandmother Téma as a living link with the past. Journeys, real and imaginary, create narrative momentum, whilst photographs are reproduced and recrafted in both comics as momento mori of a lost family past. In both Maus and Nous n'irons pas voir Auschwitz, black-and-white drawings are used to suggest a pared down connection with the past in a documentary style aesthetic. Yet, there are significant departures in the use of the comics medium as a vehicle of memory. Nous n'irons pas voir Auschwitz eschews the animal fable approach of Maus for a reportage style that charts the brothers' journey through contemporary Poland. The camp symbolism so central to Maus (stripped pyjamas, the emaciated bodies of prisoners) is completely absent from the narrative. The claustrophobic thick panel frames of Maus, that Spiegelman himself has likened to "coffins of memory" (Chute 2016, 194), are replaced by borderless images that spread outwards in favour of a connective history of peoples and cultures. Varied in size and shape, the borderless panels of Nous n'irons pas voir Auschwitz gesture at the openness inherent in Dres's Holocaust encounters and his willingness to follow the flow of memory. These multiple circuits of memory for the third generation are well illustrated in the final panel of the comic (Figure 2).

The autobiographical narrator imagines the coming together of Tema's parents, Téma herself and himself at his grandmother's graveside in the cemetery in Bagneux in an act of intergenerational solidarity. ${ }^{14}$ Here, Téma is flanked by portrait images of her rediscovered parents from Poland whose faces are projected onto their gravestones as if imaginatively transported from Poland. This is a reunion in which the autobiographical narrator has his place as the third generation. He has made a difference by correcting the misspelling of his grandmother's name - from the Paris prefecture's "Thérèse Baran" to her Polish family name "Téma Barab." ${ }^{15}$ As the written text makes clear, these erroneous linguistic transpositions risk effacing an already fragile family heritage: "Tragic, how these tiny acts of carelessness can impact a family's destiny forever. Perhaps this story will help put things back in order" (Dres 2012, 186). As a link in the chain of memory transmission, the third generation is probably the last to be able to "put things back in order" and ensure the safe passage of such memories into the future.

\section{Conclusion}

What can Nous irons pas voir Auschwitz and the case of France tell us about our changing relationship to the Holocaust as a living connection with this past disappears? Firstly, Nous n'irons pas voir Auschwitz is testament to a renewed urgency to listen to memories and histories, rendered indistinct by time, geographical distance and language. These stories 
She's buried with strangers from my

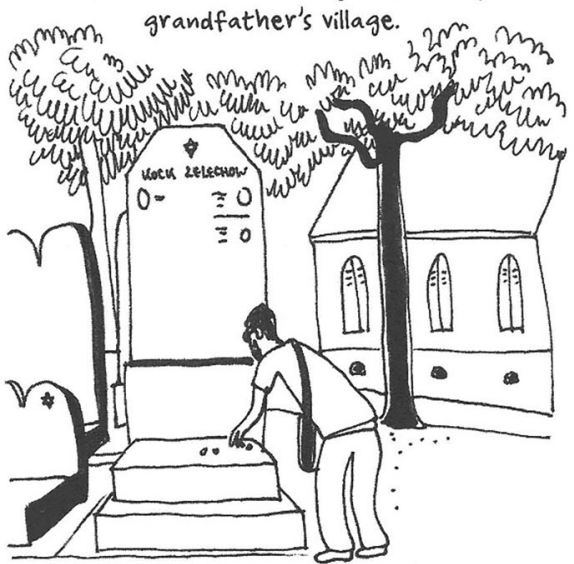

Thanks to the translation talents of the Parisian préfecture, my grandfather Simchy Dres became Simon Dres, and my grandmother Tema Barab, Thérèse Baran. She will never have the same name on her grave as her parents.

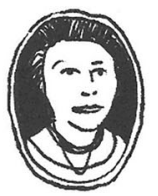

\section{TÉMA DRES NËE BARAN $1912-2009$}

Tragic, how these tiny acts of carelessness can impact a family's destiny forever.

Perhaps this story will help put things back in order.

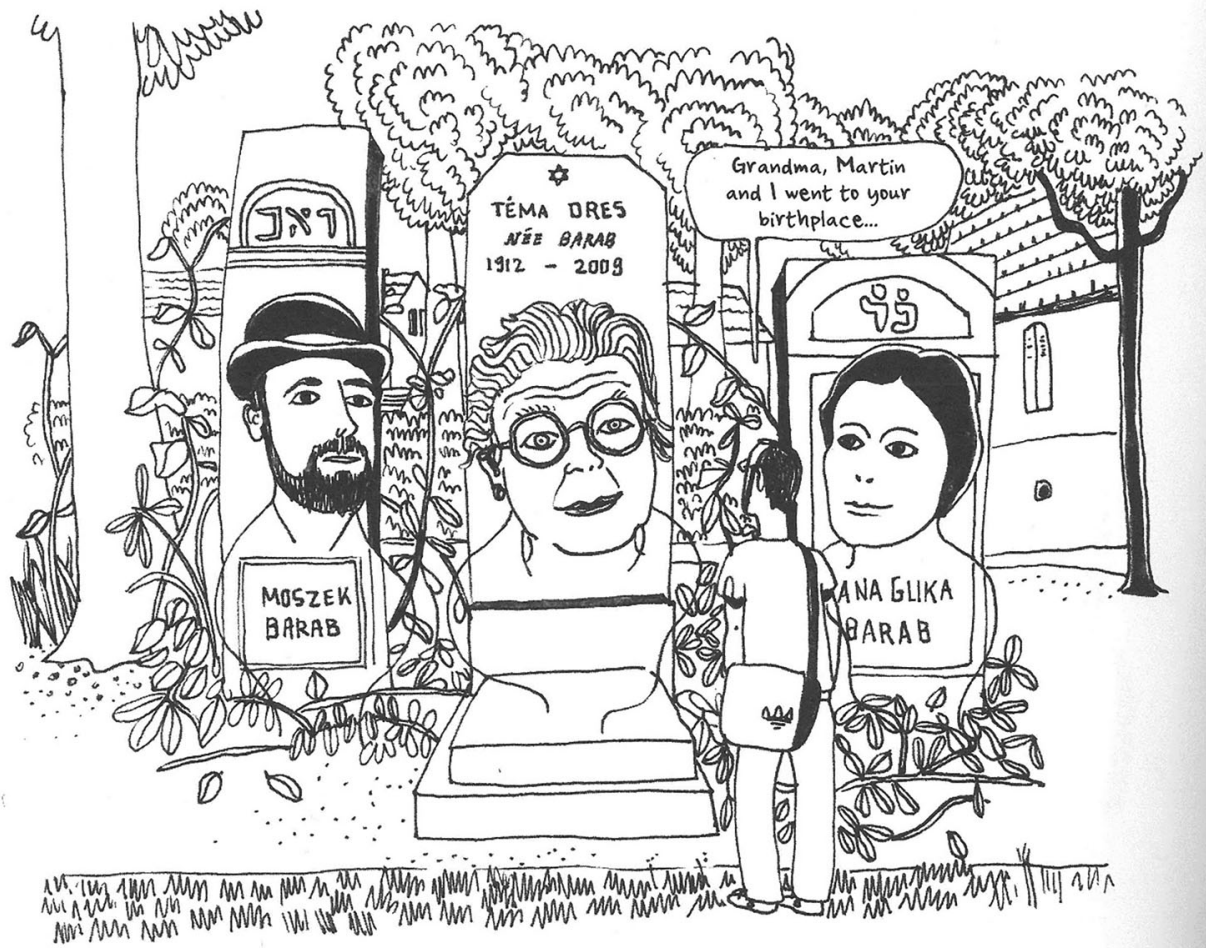

Figure 2. Nous n'irons pas voir Auschwitz, Jérémie Dres, éditions Cambourakis (2011), translated as We Won't Go and See Auschwitz, SelfMadeHero (2012): 186, reproduced with the kind permission of the author.

are encapsulated in the fading family photographs that are redrawn in the comic book and reproduced as memory objects in the appendix. This attentive listening opens a space for reflection on transnational histories and sites of memory. Dres challenges the westernization of the Holocaust with Auschwitz at its centre, highlighting the different Holocaust 
stories and perspectives with which Central and Eastern European communities identify. The comic positions the grandchildren of Holocaust survivors, witnesses and exiles as active participants in this rememorialization of the Holocaust. Secondly, Dres's comic book helps us to rethink generation as the determining paradigm for the transmission of post-war Holocaust memories. As the comic book contends, there is no one single experience of living as a Jew in wartime and post-war Poland and France and there are varied and differentiated post-Holocaust Jewish identities and trajectories. It may even be, as Gary Weissman contends, that we are approaching a time when family transmission will no longer be the privileged model "to dramatize the condition of all would be guardians of Holocaust memory” (2017, 181). Dres's comic book underscores the necessity of contextualizing generation as one factor in the emergence of Holocaust narratives. Equally important is national context and, in the case of France, a culture of commemoration manifest in the 2017 exhibition on comics and the Holocaust at the Mémorial de la Shoah. Finally, and crucially, Nous n'irons pas voir Auschwitz directs our attention to the comic book as an evocative vehicle of Holocaust remembrance. In Dres's comic book, the choice to delocalize the memory of the Holocaust, to untie it from its mooring in Auschwitz as the Holocaust lieu de mémoire par excellence, gives shape to family stories that fall outside the scope of official commemoration and the mantra of "a duty to remember." By representing the Holocaust within the pages of the comic book, Dres also encourages engagement with the Holocaust through the haptic work of drawn words and images. This is a sensory act that allows the ripples of the Holocaust to be felt by later generations in an intensely personal and artisanal aesthetic. "Not seeing Auschwitz" may, paradoxically, mean seeing the Holocaust in greater granularity and listening may lessen the weight of a monumental past that will soon persist only as cultural memory.

\section{Notes}

1. Dres's comic book has been translated into English as We Won't Go and See Auschwitz (2012); into Italian as Noi non andremo a vedere Auschwitz (2012) and into Polish as Nie pojedziemy zobaczyć Auschwitz (2013). All quotations are taken from the English translation.

2. Whilst this is a singular example from the French context, comic book representations of the Holocaust from third-generation artists are evident in other cultures, see, for example, American author, Amy Kurzweil's Flying Couch: A Graphic Memoir (2016) and Israeli artist, Rutu Modan's The Property (2013).

3. See Astro (2017) for an analysis of third-generation Holocaust narratives in French and Spanish. He does not discuss Dres's work or comic books as a medium for memory work.

4. Delorme: "récits mémoriels historiques": http://cdhlemag.com/2015/06/rencontre-avecisabelle-delorme/.

5. See the online catalogue for the exhibition "Shoah et bande dessinée: tabou ou totem?" at the Mémorial de la Shoah in Paris (19 January to 30 October 2017): http://expo-bd. memorialdelashoah.org/expositions.html.

6. The exhibition "Shoah et bande dessinée: tabou ou totem?" at the Mémorial de la Shoah goes further back and identifies one of the first drawn witness accounts of the Holocaust as Horst Rosenthal's 15-page album Micky au camp de Gurs, produced in 1942. Horst would be deported and murdered in Auschwitz.

7. The rounding up, internment and deportation of over 12,000 Jewish people on the nights of the 16 and 17 July 1942 by French policemen has come to represent the Vichy's regime's broader collusion with the Nazi occupier and the enactment of the Holocaust on French 
soil. For a discussion of the memory debates surrounding this event and its commemoration, see Clifford (2013).

8. See Jonathan Haudot in Shoah et bande dessinée (2012, 72-98) for an analysis of the series and subsequent court cases brought against its authors by associations of concentration camp survivors.

9. See Didier Daeninckx and Asaf Hanuka, Carton Jaune! ([1999] 2012) which charts the wartime history of the fictional figure of Jacques Benzara, a Jewish-Tunisian footballer. The comic draws on the real-life story of Jewish-Tunisian boxer Victor Perez.

10. See Tardi (2012, 2014); Silloray (2011) and, more recently, Gautier and Oger (2017).

11. See Dres's website for a comprehensive overview of his work and outputs: http://www. jeremiedres.com/.

12. Dres's title echoes other French narratives, both fictional and testimonial, that represent wartime memories. Firstly, Charlotte Delbo's Aucun de nous ne reviendra (1965), an account of her imprisonment in Ravensbrück concentration camp, can be inferred from Dres's title in its play on negation. A further literary allusion could also be to Alain Resnais's and Marguerite Duras's Hiroshima mon amour (1959) where the main female protagonist repeatedly tells her Japanese lover "tu n'as rien vu à Hiroshima" (You didn't see anything in Hiroshima). My thanks to Max Silverman and Chris Reyns-Chikuma, respectively, for pointing out these possible intertextual references.

13. See Cole (2000) for a critical examination of the misuses of narratives of the Holocaust in American culture.

14. Berger $(2017,85)$ rightly points to the parallels between the endings of Nous n'irons pas voir Auschwitz and the final panels of Maus.

15. We can speculate also on bureaucratic carelessness as the reason for the changing patronymic of the author himself - from the Polish "Dress" to "Dres". The loss of family histories, as an unintended consequence of the misspelling of family names, is dwelt upon in historian Ivan Jablonka's investigation into the life and death of his Jewish-Polish paternal grandparents (2012).

\section{Acknowledgements}

I would like to thank Margaret Atack and Hanna Diamond for their insightful feedback during the writing of this article. Many thanks also to colleagues at the University of Ghent and KU Leuven for the opportunity to present and discuss aspects of this article at the "Comics and Memory" conference, held in Ghent in April 2017, and to colleagues at the University of Southampton for their feedback during a one-day symposium on visual cultures and the Holocaust, also in April 2017.

\section{Disclosure statement}

No potential conflict of interest was reported by the author.

\section{Notes on contributors}

Claire Gorrara is Professor of French Studies at Cardiff University. She has written extensively on memories and representations of the Second World War in French culture. She is currently researching visual cultures of war and conflict. She has recently published articles on British photography and the Normandy Landings in the Journal of War and Culture Studies (2016) and has an article forthcoming on comics and the Algerian War in French Politics, Culture and Society (2018).

\section{ORCID}

Claire Gorrara (D) http://orcid.org/0000-0003-0732-7666 


\section{References}

Aarons, Victoria, ed. 2016. Third-Generation Holocaust Narratives: Memory in Memoir and Fiction. Lanham: Lexington Books.

Aarons, Victoria, and Alan L. Berger. 2017. Third-Generation Holocaust Representation: Trauma, History and Memory. Evanston, IL: Northwestern University Press.

Assmann, Jan, and John Czaplicka. 1995. "Collective Memory and Cultural Identity." New German Critique 65: 125-33.

Astro, Alan. 2017. "Avatars of Third Generation Narratives in French and Spanish." In ThirdGeneration Holocaust Narratives: Memory in Memoir and Fiction, edited by Victoria Aarons, 103-30. Lanham: Lexington Books.

Azouvi, François. 2012. Le Mythe du grand silence: Auschwitz, les Français, la mémoire. Paris: Fayard.

Berger, Alan. 2017. "Life after Death: A Third Generation Journey in Jérémie Dres's We Won't See Auschwitz." In Third-Generation Holocaust Narratives: Memory in Memoir and Fiction, edited by Victoria Aarons, 73-87. Lanham: Lexington Books.

Bernstein, Michael André. 1998. "Victims-in-Waiting: Backshadowing and the Representation of European Jewry." New Literary History 29 (4): 625-651.

Bruttmann, Tal. 2009. "The Holocaust Through Comics." In Re-examining the Holocaust Through Literature, edited by Anjke Kluge and Benn E. Williams, 173-200. Cambridge: Cambridge Scholars.

Calvo, Edmond-François, and Victor Dansette. 1995. La Bête est morte: la guerre mondiale chez les animaux. Paris: Gallimard.

Cases d'Histoire. 2015. "Rencontre avec Isabelle Delorme." http://cdhlemag.com/2015/06/ rencontre-avec-isabelle-delorme/.

Chute, Hillary. 2016. Disaster Drawn: Visual Witness, Comics and Documentary Form. Cambridge, MA: Belknap Press, Harvard University Press.

Clifford, Rebecca. 2013. Commemorating the Holocaust: The Dilemmas of Remembrance in France and Italy. Oxford: Oxford University Press.

Cole, Tim. 2000. Selling the Holocaust: From Auschwitz to Schindler. How History is Bought, Packaged and Sold. London: Routledge.

Croci, Pascal. [1999] 2012. Auschwitz. Paris: Emmanuel Proust Editions.

Daeninckx, Didier, and Asaf Hanuka. [1999] 2012. Carton Jaune! Paris: Emmanuel Proust Editions.

Dony, Christophe, and Caroline van Linthout. 2010. "Comics, Trauma and Cultural Memor(ies) of 9/11.” In The Rise and Reason of Comics and Graphic Literature: Critical Essays, edited by Joyce Goggin and Dan Hassler-Forest, 178-187. Jefferson, NC: McFarland.

Dreifus, Erika. 2017. “A Special Kind of Kinship: On Being a '3G' Writer.” In Third-Generation Holocaust Narratives: Memory in Memoir and Fiction, edited by Victoria Aarons, 1-16. Lanham: Lexington Books.

Dres, Jérémie. 2011. Nous n'irons pas voir Auschwitz. Paris: Editions Cambourakis.

Dres, Jérémie. 2012. We Won't Go and See Auschwitz. Translated by Edward Gauvin. London: SelfMadeHero.

Dres, Jérémie. 2014. Dispersés en Babylone. Paris: Gallimard.

Gautier, G. P., and T. Oger. 2017. Ma guerre de la Rochelle à Dachau. Paris: Rue de Sèvres.

Haudot, Jonathan. 2012. Shoah et bande dessinée. Paris: L'Harmattan.

Hirsch, Marianne. 1997. Family Frames: Photography, Narrative and Postmemory. Cambridge, MA: Harvard University Press.

Hirsch, Marianne. 2012. The Generation of Postmemory: Writing and Visual Culture After the Holocaust. Columbia: Columbia University Press.

Hoffman, Eva. 2004. After Such Knowledge: Memory, History, and the Legacy of the Holocaust. New York: PublicAffairs.

Jablonka, Ivan. 2012. Histoire des grands-parents que je n'ai pas eus: une enquête. Paris: Seuil. Jilovsky, Esther. 2015. Remembering the Holocaust: Generations, Witnessing and Place. London: Bloomsbury. 
Kurzweil, Amy. 2016. Flying Couch: A Graphic Memoir. New York: Black Balloon.

Mémorial de la Shoah. 2017. Exhibition "Shoah et bande dessinée." http://expo-bd. memorialdelashoah.org/expositions.html.

Modan, Rutu. 2013. The Property. London: Jonathan Cape.

Rousso, Henry. 1987. Le Syndrome de Vichy: de 1944 à nos jours. Paris: Gallimard.

Silloray, Florent. 2011. Le Carnet de Roger. Paris: Editions Sarbacane.

Spiegelman, Art. 2003. The Complete Maus. London: Penguin Books.

Tardi, Jacques. 2012. Moi René Tardi, prisonnier de guerre au Stalag IIB. Paris: Casterman.

Tardi, Jacques. 2014. Moi René Tardi, prisonnier de guerre au Stalag IIB: mon retour en France. Paris: Casterman.

Weissman, Gary. 2017. “Against Generational Thinking in Holocaust Studies.” In Third-Generation Holocaust Narratives: Memory in Memoir and Fiction, edited by Victoria Aarons, 159-184. Lanham: Lexington Books.

Wolf, Joan D. 2003. Harnessing the Holocaust: The Politics of Memory in France. Stanford: Stanford University Press. 